\title{
Upregulation of CD271 Transcriptome in Breast Cancer Promotes Cell Survival via NFKB Pathway
}

Ramla Shahid ( $\nabla$ ramla_shahid@comsats.edu.pk)

COMSATS University Islamabad https://orcid.org/0000-0001-7707-6431

Nabiha Bashir

COMSATS University Islamabad

Mehreen Ishfaq

COMSATS University Islamabad

Kehkashan Mazhar

KRL Hospital

Jahangir Sarwar Khan

Rawalpindi Medical University

\section{Research Article}

Keywords: CD271, NF-KB1, breast cancer, MCF7-CSCs, breast cancer stem cells, G-quadraplex

Posted Date: August 10th, 2021

DOl: https://doi.org/10.21203/rs.3.rs-781532/v1

License: (c) (1) This work is licensed under a Creative Commons Attribution 4.0 International License.

Read Full License 


\section{Abstract}

\section{Background}

Biological treatment of many cancers currently targets membrane bound receptors located on a cell surface. We are in a great to need identify novel membrane proteins associated with migration and metastasis of breast cancer cells. CD271, a single transmembrane protein belongs to tumor necrosis factor receptor acts and play its role in proliferation of cancer cell. The purpose of this study is to investigate the role of CD271 in breast cancer.

Methods and Results

In this study we analyzed the expression of CD271 in breast tumor tissue, breast cancer cell line MCF7 and isolated cancer stem cells (MCF7-CSCs) by quantitative real-time polymerase chain reaction (RTqPCR). CD271 was upregulated among breast cancer patients in all age groups. Within the promoter region of $\mathrm{CD} 271$, there is a binding site for NF-KB1 which overlaps a putative quadraplex forming sequence. While CD271 also activates NF-kB pathway, down regulation of CD271 through quadraplex targeting resulted in inhibition of NF-KB and its downstream targets Nanog and Sox2

\section{Conclusion}

In conclusion, CD271 and NF-KB are interrelated to each other. Upon CD271 inhibition, the NF-KB expression also reduces which then effected the cell proliferation and migration. These results suggest that NF-KB is regulated by CD271 is playing a crucial role in cancer development and could be a potential therapeutic target.

\section{Introduction}

Breast cancer is the serious health issue and 2nd leading cause of mortality among all other cancer accounting for $11.7 \%$ of cases worldwide[1,2] .Breast tumors are known to be composed of diverse group of cells including cancer stem cells (CSCs).CSCs have an ability to control the tumorigenicity and resist conventional therapies. Hence, they are the main cause of the relapse of cancer[3]. Therefore, to prevent breast cancer recurrence, effective treatment involves elimination of CSCs[4]. CD271, also known as nerve growth factor receptor (NGFR) is a transmembrane protein. It belongs to the tumor necrosis factor receptor (TNFR) superfamily [5] and plays a pivotal role in development and regeneration of sympathetic and sensory nervous system [6].It performs a dual role by acting as an antiproliferative agent which control cell apoptosis by the facilitation of cytochrome $\mathrm{C}$ release from mitochondria and activation of Caspases 9, 6 and 3. It has also been involved in cell proliferation and promote invasiveness by MAPK and (PI3K)/ AKT signaling pathway[7-10] . In case of carcinoma, it appears to involved in inducing apoptosis in prostate, bladder, stomach and liver cancer[11-14]. Whileits proliferative role has been reported in thyroid carcinoma and melanoma $[15,16]$. Several studies have identified CD271 as a neural 
crest and mesenchymal stem cell marker while its expression was also reported in other stem cells such as laryngeal epidermal, esophageal and corneal regenerative epithelia [16-21].

In case of breast cancer several studies have shown the induced expression of CD271 in breast carcinoma [5],[22],[23]. The role of CD271 in cancer development and its progression is not fully understood and different results have been reported [10]. Tumor necrosis factor receptor (TNFR) family is known to activates NF-kB pathway along with other factors such epidermal growth factor receptor (EGFR), toll-like receptor (TLR) and cytokines receptors [24]. CD271 being a member of TNFR is involved in the activation of NF-KB pathway to mediate cell proliferation and survival[5, 9, 25].The signaling pathway of NF-KB is widely associated with cancer development and progression .NF-KB is very important transcription factor which plays crucial role by binding to consensus DNA sequence at the promoter region to transcriptionally regulates target genes.[26]. It is also reported to be involved in controlling the stemness and survival of cancer stem cells [27]. It does so by transcriptional regulating sox2 and Nanog both are very crucial for the maintenance of stem cells [28]. We hypothesized that activation of NF-KB by CD271 could facilitate the cell survival and proliferation through Nanog and Sox2 so can promote carcinogenesis (Fig1).

\section{Methodology}

\section{Exclusion and Inclusion Criteria}

Patients suffering from breast cancer were included in the study and patients with any infection was excluded. Patients included must be histologically confirmed for different grades of cancer (Grade I, II and III).The samples were taken at the time of surgery, along with the histopathological reports.

\section{Breast Biopsies, Cell Culture and Drug preparation.}

Breast tumor confirmed pathologically with adjacent normal tissues as control, were collected from 60 breast cancer patients, immediately after surgery from PIMS (Pakistan Institute of Medical Sciences) and Holy family hospital after taking consent from the patients. The excised tissues were stored in $1 \mathrm{X}$ PBS(Gibco) at $-20 \otimes C$.

Clinical pathological features studied were age, tumor types, tumor grade and Receptor's profile as indicated in Table 1.

Human Breast cancer cell line (MCF-7) was obtained from American Type Culture Collection (ATCC). The cell line was cultured in RPMI 1640 media (Gibco,USA) supplemented with $10 \%$ fetal bovine serum (FBS) and $1 \%$ GPSS (L-Glutamin, pyruvate, streptomycin-pencillin) maintained at 37凶C and 5\% CO2 in a humidified atmosphere in T25 flask. Thymoquinone was purchased from (Sigma-Aldrich) and 2mM stock was prepared in DMSO. Working concentrations were prepared by diluting the stock in freshly prepared RPMI 1640 media. 
After the cells were $>80 \%$ confluent and growing exponentially in T25 flask, they were counted and plated in 96 well plate with variable concentrations of $T Q$ in $\mu \mathrm{M}(160,80,40,20,10,5$ and 2.5$)$ to measure the IC50.

\section{Cytotoxicity Assay}

The anti-proliferative effect of thymoquinone was determined by MTT [3-(4,5-Dimethylthiazol-2-yl)-2,5diphenyl-2H-tetrazolium bromide] assay. Briefly, $10^{3}$ cells were counted and seeded in triplicates in each well of 96 well microtiter plate followed by overnight incubation. After 24 hours cells were exposed to increasing concentrations of TQ $(2.5,5,10,20,40,80$ and $160 \mu \mathrm{M}$ doses $)$ for the next 24 hours. TritonX100 (78ppm) was used a positive control and the blank (RPMI 1640 medium) for calculating viability. The cells were treated with MTT $(10 \mu \mathrm{l})$ solution after 24 hours and incubated for 3 hours to reduce the yellow dye to purple formazan crystals. After that medium was removed and $100 \mu \mathrm{l}$ of stopping solution (10\% SDS in $1 \mathrm{M} \mathrm{HCL}$ ) was added to dissolve the crystals and further incubated for overnight. The absorbance was recorded at $570 \mathrm{~nm}$ of each well by using microplate reader (FLUOstar Omega) and viability was calculated.

$\%$ cell viability $=\{(A t-A b) /(A c-A b)\} \times 100$

A graph of viability versus drug concentration was used to calculate IC50 values for MCF-7 cell line. The IC50 of TQ was obtained as $70 \mu \mathrm{M}$. For expressional analysis $0.5 \times 10^{5} / \mathrm{ml} \mathrm{MCF-7} \mathrm{cells} \mathrm{were} \mathrm{seeded} \mathrm{in}$ three 6 well plates. After $24 \mathrm{hrs}$ of incubation, TQ was added in varying concentrations $(40,50,60,70$ and $80 \mu \mathrm{M})$ in their respective wells in three plates. The next day plates were taken out, trypsinzed and RNA was isolated.

\section{Isolation of Cancer Stem Cells from MCF-7 (MCF7-CSCs)}

The breast cancer stem cells were isolated by using the MAG-iso ${ }^{\text {TM }}$ (Cat No. - K10103) kit. The MAGiso ${ }^{\mathrm{TM}}$ Human Isolation Kit is designed to isolate BCSCs based on $\mathrm{CD} 24^{-/ / \text {low }}$ and $\mathrm{CD} 44^{+/ \text {high }}$ surface markers. Cultured MCF-7 cells in T75 flask with $80 \%-90 \%$ confluency was trypsinized and counted by hemocytometer. The cancer stem cells were isolated by untreated MCF-7 cells is considered as NTC. For the treated cells doses of thymoquinone were selected as $50 \mu \mathrm{M}$ and $60 \mu \mathrm{M}$. Initially $1 \times 10^{6}$ cells were seeded in 6 well plate and followed by overnight incubation. After 24 hours, cells were exposed with TQ doses and further kept for overnight incubation. The next day cells of each well were trypsinized and counted. The starting population of MCF-7 cells for isolation of CSCs should be as low as $1 \times 10^{6} / \mathrm{ml}$ according to the protocol. The cells were then resuspended in cold Iso-Mag buffer (2खC-8囚C) to proceed kit isolation procedure. Isolated BCSCs were suspended in trizol reagent for further analysis.

\section{Isolation of RNA}

Isolation of RNA from breast biopsies, MCF-7 cell line and MCF7-CSCs were carried out by trizol reagent (Invitrogen, USA) according to manufacturer's protocol. The extracted RNA was analyzed on 1X TBE gel 
to confirm the isolated RNA. Quantification of RNA was done by UV spectrometer (Implen Nanophotometer) and absorbance was measured at 260/280nm. Extracted RNA was stored in DEPC water at $-20 \rrbracket C$.

\section{Quantitative Real Time PCR}

cDNA was prepared from 500ng of RNA by two step protocol using thermo cycler (Applied Biosystem). The expressional analysis of CD271, NF-kB1, $\beta$-actin, Sox2 and Nanog was carried out by $5 x$ SolisGreen ${ }^{\circledR}$ qPCR mix (Solis Biodyne) on Step 1 plus PCR system (Applied Biosystem). Primers were designed by Primer3plus tool with the conditions indicated in (Table 2). $\beta$-actin was used as an internal control. The thermal cycler condition was $95 \llbracket \mathrm{C}$ for 12 mins initial denaturation followed by 35 cycles of $95 \rrbracket \mathrm{C}$ for $45 \mathrm{~s}$, annealing temperature of desired primers for 30 s followed by extension at $72 \varangle \mathrm{C}$ for $30 \mathrm{~s}$. The data acquisition was done on extension step. The expressional analysis of CD271, NF-KB1,Sox2 and Nanog relative to endogenous control $\beta$-actin was performed by Livak methods (of $2^{\wedge}$-delta $\mathrm{Ct}$ ) [29] .

\section{BrdU proliferation assay}

The assay was performed using BrdU Cell Proliferation Assay Kit (Biovision Incorporated) following the manufacturer's instructions. MCF-7 cells were cultured in 96 well plate at 5000 cells/well and treated with TQ concentrations $(50 \mu \mathrm{M}, 60 \mu \mathrm{M}$ and $70 \mu \mathrm{M})$ for $24 \mathrm{hrs}$. BrdU solution was added into each well and incubated at $37^{\circ} \mathrm{C}$ for $3 \mathrm{hrs}$ before fixation. BrdU positive cells were detected by measuring the absorbance at $450 \mathrm{~nm}$ by microplate reader.

\section{Invitro scratch wound healing assay.}

This assay was used to study the effect of TQ on the migration of MCF-7 cell line. Cells were cultured in $60 \mathrm{~mm}$ petri dish under normal cultural condition and allowed to reach confluency. After reaching $89-90 \%$ confluency, one plate is taken as control and other one is treated with $70 \mu \mathrm{M}$ TQ. Pre-sterilized $200 \mu$ tip was used to create a scratch on both plates. The status of scratch wounds was monitored at the beginning of the assay ( $0 \mathrm{hr}$ ) and after regular intervals ( $24 \mathrm{hr}$ and $48 \mathrm{hrs}$ ) and images collected by Keyence bz-x700 microscope.

\section{Computational Analysis}

The sequence of CD271 promoter (500bp upstream form transcription start site) was retrieved from Ensemble (ENST00000172229.8). QGRS mapper (G-quadraplex analysis tool) was used to locate Gquadruplex at CD271 promoter [30]. The binding site of transcription factor NF-KB1 at CD271 promoter was identified by ContraV3 bioinformatics tool [31].

\section{Statistical Analysis}

IBM SPSS (version 25) was used to apply unpaired student's $t$ test and one-way Analysis of variance (Anova) for evaluating statistical significance of CD271 expression, and the significance between CD271 
expression and clinical pathological features in cancer patients. The data analysis of CD271, NFKB1, Sox2 and Nanog in MCF-7 and MCF7-CSCs was also done by paired student's $t$ test and one-way Anova. $R$ software was used for the regression and correlation analysis. The data withp value less than 0.05 was considered statistically significant.

\section{Results}

The regulatory role of CD271 in the incidence of breast cancer has been reported previously[32].To analyze it in our cohort, the expression profile of CD271 was examined in breast cancer patients initially. Further analysis was done to elucidate the mechanism of CD271 in regulating NF-kB pathway.

\section{Expression of CD271 in Breast Biopsies and pathological features}

The expression was induced by 4 folds in tumor samples when compared to adjacent controls $(p=0.0002)(F i g ~ 2 A)$. The result indicated that CD271 was significantly induced among patients than their adjacent control tissues.

To understand the role of CD271 in the prognosis and onset of disease, the involvement of different clinical parameters in association with the CD271 expression level was taken into consideration. These included analyzing the expression on the bases of age, types of breast carcinoma, tumor grading, and hormonal receptors. In our cohort the expression was consistently induced regardless of different clinical factors. That means the mechanism of induction of CD271 in breast cancer is independent of these factors and is exclusive to breast cancer (Fig2B).

\section{Expression analysis of CD271 in MCF-7 and MCF7-CSCs}

CD271 expression was measured in breast cancer cell line (MCF-7) and extracted cancer stem cells MCF7-CSCs. As CD271 is a member of TNFR, so we hypothesized that it has stimulatory role in NF-KB regulation. Being a transcription factor, NF-KB regulates the expression of its downstream targets sox 2 \& Nanog, which are important factors for maintaining the survival of MCF-7 cell line along with MCF7CSCs. Therefore, expression of NF-KB1 (subunit of NF-KB) and its regulatory genes sox2 and nanog were also elucidated.

Expression of CD271 mRNA was 2 folds high $(p=0.03)$ in MCF7-CSCs in comparison to MCF-7 cell line. Sox2 and Nanog also showed significant upregulation in MCF7-CSCs then MCF-7 cell line. (Fig 2C). The correlation was also analyzed between CD271 and NF-KB1 by Kendall's rank correlation test in MCF7 cell line. A strong positive correlation $(p=0.01$, tau $=1)$ was found between CD271 and NF-kB1 indicating the increase of NF-KB1 expression with the increase of CD271 expression (Fig 2D)

\section{Computational Analysis}

QGRS mapper was used to identify the G-rich sequences (G-quadruplexes/G4) within the promoter region of CD271 gene, 500 bps upstream to the TTS. Promoter analysis revealed the presence of a putative G- 
quadruplex forming sequence (5-GGGGAGGGGTGGGGATGGGG-3) at -452 to -471 position on the promoter of CD271. We searched the binding site of NF-KB subunits on CD271 promoter and found the binding of NF-KB1 (-460 to $-472 \mathrm{pb}$ ) on the G-quadraplex sequences upstream of transcription start site of CD271 (Fig 3A). Promoter quadraplex has been shown to regulate the transcription in both positive and negative way [33]. CD271 region from (-452 to -471) upstream of transcription start site TSS appears to be very crucial, the folding of DNA strand because of G-quadraplex interfere with the binding of NF-KB1 and effects the transcription of CD271(Figure 3B).

\section{Expression of CD271 in MCF-7 cell line}

G-quadruplex structures in the gene promoters is linked with transcriptional activation or repression. Consequently, interaction of small molecules with such G-quadruplexes may modulate transcription. Thymoquinone (TQ) has been reported to bind with G-quadraplex and interfere with DNA structure and inhibits the DNA synthesis, transcription, and viability of cell[35]. [36].Therefore, we treated the cells with TQ to block the binding of NF-KB to CD271 promoter (Fig 4A).

The effect of TQ on CD271 as quadraplex binder was studied on MCF-7 cell line. The expression of CD271 was inhibited in dose dependent manner in MCF-7 cell line. NF-KB1 also showed decrease expression with increasing dose of TQ. Thus, TQ has downregulated mRNA expression of CD271 and its downstream target NF-KB1 (Fig 4A).

\section{Expression of CD271 in MCF7-CSCs}

The effect of expression repression of CD271 in CSCs isolated from MCF-7 cell line was analyzed. The expression of CD271 was inhibited after the TQ application. The study was further expended towards the downstream regulator of CD271 to check if the lower transcription can affect its downstream targets NFKB1, sox2 and Nanog. Overall. It was found that TQ downregulated the expression of all the selected genes in a dose dependent manner as illustrated in Fig 4B and 4C.

\section{TQ inhibits proliferation and migration of MCF-7 cells.}

The proliferation of BrdU incorporated MCF-7 cells were measured in presence of TQ. TQ has shown the overall significant effect $(p=0.002)$ by decreasing the proliferation of MCF-7 cells, while $70 \mu \mathrm{M}$ was measured the most effective dose ( $p=0.001)$ for controlling the proliferation of MCF-7cells (Fig 4D). In case of migration, untreated MCF-7 cells taken as control have shown the movement towards the center of wound and completely healed the scratch after 48hrs. While the cells treated with TQ showed slow movement towards the center and wound is still not healed after 48hrs (Fig 4E). This shows the migration of cells are affected by the inhibition of CD271 expression by TQ. Hence, CD271 can be considered as a potential therapeutic target to control the cell proliferation and migration. 


\section{Discussion}

Tumor recurrence is controlled by stem-like cancer cells termed as cancer stem cells [37]. Lots of research is going to find the way to cease the proliferative capability of CSCs to reduce the chance of cancer relapse. CD271, a receptor for nerve growth factor has a greater capacity of tumor initiation. CD271 ${ }^{+}$ $\mathrm{CD} 44^{+}$subpopulation reported to contain the more stem cell like cells having an enhanced tumorigenic, proliferative and metastatic potential [38-41]

CD271 has dual role being proliferative to stimulate survival or anti-proliferative to stimulate cell death $[32,42]$. In this study the expression of CD271 was investigated in breast cancer patients along with cancer stem cells (MCF7-CSCs) to define its role as proliferative or anti-proliferative. We found that CD271 was induced individually of clinical factors in all breast cancer biopsies when compared to adjacent non-cancerous control. It assumed that CD271 might modulate the proliferation of breast cancer cells as consistent with previous studies $[6,17,21]$. The established markers for the breast cancer are specific with certain clinical parameter such as Human epididymis protein 4 (HE4) is associated with ductal carcinoma [43], CD24 with invasive breast carcinoma and early-stage cancer [44, 45], ki-67 is associated with higher stage and higher-grade tumor [46] while CD271 in this study was induced independent with any clinical parameter. By analyzing these results, we can see the role of CD271 as facilitator of cancer incidence which helps in cancer cell survival independent of any clinical parameters.

CD271 controls the proliferation of cells by activation of MAPK, (PI3K)/ AKT and NF-KB signaling pathway $[32,47]$. Our data suggests that induced CD271 might plays a contributing role in the proliferation and metastasis of cancer cells through NF-KB pathway and its downstream targets Nanog and Sox2. Correlation study also showed the positive correlation between both CD271 and NF-KB. Induction of CD271 in MCF-7 and MCF7-CSCs can also contributes towards the more enhanced proliferation of these cells. Upon treatment with TQ, a G-quadraplex binder, CD271 expression was reduced which also reduces the cell movement in the wound healing assay. Bioinformatics analysis showed the binding site of NF-KB1 at the promoter region of CD271 which overlaps with G-quadraplex sequences. NF-KB subunits NF-KB1 and NF-KB2 after translocation to the nucleus, dimerize and bind to the promoter sequences of target gene CD271 [34]. One of the previous study reported the inhibitory binding of TQ to the NF-KB2 subunit which do not allow NF-KB2 to bind with NF-KB1 [48]. This ceases the binding of NF-KB dimers to its downstream genes. Reduced CD271 expression by TQ might be due to its inhibitory effect on NF-KB binding to CD271 promoter. There might be a possibility of direct binding of TQ to the quadraplex at CD271 promoter which in turn prevent the interaction of NF-KB1 for transcription activation. Bioinformatic analysis was also performed to identify G-rich sequences or G-quadraplex in the promoter region of Sox 2 and Nanog genes. No G-rich sequences were identified with in promoter region of Sox 2 and Nanog genes. In our results we have also observed the downregulation of these genes in dose dependent manner. This could be corresponded with the lower expression of CD271 which effected the further cascade including NF-KB1, Sox2 and Nanog. It is therefore suggested that TQ is reducing the expression of CD271 and its downstream target genes by binding with the CD271 G-quadraplex. Thymoquinone also suppress the TNFR induced NF-KB activation by one of the study [49] which more 
emphasizes the inhibitory effect of TQ towards the cancer cell survival. This supports our hypothesis that downregulation of CD271 will in turn downregulates NF-KB1 and its downstream targets, effecting the cancer cell growth and migration.

Initially we proposed the stimulating role of $\mathrm{CD} 27 \mathrm{I}$ receptor in the activation of NF-KB pathway. By computational analysis later we have found NF-KB1 binding at CD271 promoter. Here we can see NF-KB1 as a transcription factor, is facilitating the transcription of CD271. Hence the positive feedback loop can be suggested by our data as CD271 regulates NF-KB pathway and NF-KB1 as transcription factor facilitate the expression of CD271 as its target gene (Fig 5). Blocking either CD271 promoter or NF-KB1 binding by TQ can alter the expression of target gene of NF-KB pathway which include stemness markers Sox2 and Nanog involved in proliferation and survival of cancer cells and cancer stem cells.

\section{Conclusion}

In conclusion this study showed that induced CD271 expression is independent of any clinicopathological feature. It may regulate the most important transcription factor NF-KB and its target genes involved in cancer stemness and proliferation. Inhibiting CD271 can downregulates NF-KB and its targets gene involves in cell survival Sox2 and Nanog. CD271 here seems to be a potential target to treat breast cancer. Further study at protein level is needed to elucidate the results.

\section{Declarations}

\section{Funding}

This research did not receive any specific grant from funding agencies in the public, commercial, or notfor-profit sectors.

\section{Conflicts of Interest}

The authors declare no conflict of interest.

\section{Data availability}

The data and material analyzed during this study are available from the corresponding author on reasonable request (ramla_shahid@comsats.edu.pk).

\section{Author Contribution:}

Ramla Shahid and kehkeshan Mazhar conceptualized and designed the experiment. Nabiha Bashir and Mehreen Isfaq performed the experiments. The manuscript was written by Nabiha Bashir and edited by Ramla Shahid and Kehkeshan Mazhar.

\section{Ethical approval}


This study was approved by the ethical committee of COMSATS University Islamabad (CUI) Islamabad and was performed in agreement with the guidelines of PIMS Hospital Islamabad and Holy Family Hospital Rawalpindi Pakistan.

\section{Consent to Participate}

A written informed consent was obtained from all participants.

\section{Consent for Publication}

Participants have consented to the submission of the data.

\section{Acknowledgments}

We highly appreciated the efforts of the local hospitals (PIMS and Holy family) for providing breast cancer patient's samples. Additionally, we are thankful to Dr Muhammad Abubakar National Veterinary Laboratory NARC, Islamabad for providing us the facilities to conduct important part of the research.

\section{References}

1. Nagai H, Kim YH (2017) Cancer prevention from the perspective of global cancer burden patterns. J. Thorac. Dis.

2. Sung H, Ferlay J, Siegel RL, Laversanne M, Soerjomataram I, Jemal A, Bray F (2021) Global cancer statistics 2020: GLOBOCAN estimates of incidence and mortality worldwide for 36 cancers in 185 countries. CA Cancer J Clin. https://doi.org/10.3322/caac.21660

3. Yu Y, Ramena G, Elble RC (2012) The role of cancer stem cells in relapse of solid tumors. Front. Biosci. Elit.

4. Elbaiomy MA, Akl T, Atwan N, Elsayed AA, Elzaafarany M, Shamaa S (2020) Clinical Impact of Breast Cancer Stem Cells in Metastatic Breast Cancer Patients. J Oncol 2020: . https://doi.org/10.1155/2020/2561726

5. Deng X, Xu G, He L, Xu M (2017) p75NTR promotes survival of breast cancer resistant cells by regulating Bcl-2/Bax and MAPK pathway. Int J Clin Exp Pathol 10:11685-11694

6. Tomellini E, Lagadec C, Polakowska R, Le Bourhis X (2014) Role of p75 neurotrophin receptor in stem cell biology: More than just a marker. Cell. Mol. Life Sci.

7. Bhakar AL, Howell JL, Paul CE, Salehi AH, Becker EBE, Said F, Bonni A, Barker PA (2003) Apoptosis Induced by p75NTR Overexpression Requires Jun Kinase-Dependent Phosphorylation of Bad. J Neurosci. https://doi.org/10.1523/jneurosci.23-36-11373.2003 
8. Filipp F V., Li C, Boiko AD (2019) CD271 is a molecular switch with divergent roles in melanoma and melanocyte development. Sci Rep. https://doi.org/10.1038/s41598-019-42773-y

9. Descamps S, Toillon RA, Adriaenssens E, Pawlowski V, Cool SM, Nurcombe V, Le Bourhis X, Boilly B, Peyrat JP, Hondermarck H (2001) Nerve Growth Factor Stimulates Proliferation and Survival of Human Breast Cancer Cells through Two Distinct Signaling Pathways. J Biol Chem.

https://doi.org/10.1074/jbc.M010499200

10. Reis-Filho JS, Steele D, Di Palma S, Jones RL, Savage K, James M, Milanezi F, Schmitt FC, Ashworth A (2006) Distribution and significance of nerve growth factor receptor (NGFR/p75NTR) in normal, benign and malignant breast tissue. Mod Pathol 19:307-319 . https://doi.org/10.1038/modpathol.3800542

11. Khwaja F, Tabassum A, Allen J, Djakiew D (2006) The p75NTR tumor suppressor induces cell cycle arrest facilitating caspase mediated apoptosis in prostate tumor cells. Biochem Biophys Res Commun. https://doi.org/10.1016/j.bbrc.2006.01.073

12. Tabassum A, Khwaja F, Djakiew D (2003) The p75NTR tumor suppressor induces caspase-mediated apoptosis in bladder tumor cells. Int J Cancer. https://doi.org/10.1002/ijc.11038

13. Jin H, Pan Y, Zhao L, Zhai H, Li X, Sun L, He L, Chen Y, Hong L, Du Y, Fan D (2007) p75 neurotrophin receptor suppresses the proliferation of human gastric cancer cells. Neoplasia. https://doi.org/10.1593/neo.07175

14. Yuanlong H, Haifeng J, Xiaoyin Z, Jialin S, Jie L, Li Y, Huahong X, Jiugang S, Yanglin P, Kaichun W, Jie $D$, Daiming $F(2008)$ The inhibitory effect of $p 75$ neurotrophin receptor on growth of human hepatocellular carcinoma cells. Cancer Lett. https://doi.org/10.1016/j.canlet.2008.03.038

15. Rocha AS, Risberg B, Magalhães J, Trovisco V, de Castro IV, Lazarovici P, Soares P, Davidson B, Sobrinho-Simões M (2006) The p75 neurotrophin receptor is widely expressed in conventional papillary thyroid carcinoma. Hum Pathol. https://doi.org/10.1016/j.humpath.2005.12.016

16. Truzzi F, Marconi A, Lotti R, Dallaglio K, French LE, Hempstead BL, Pincelli C (2008) The p75 neurotrophin receptor is widely expressed in conventional papillary thyroid carcinoma. $\mathrm{J}$ Invest Dermatol. https://doi.org/10.1038/jid.2008.21

17. Betters E, Liu Y, Kjaeldgaard A, Sundström E, García-Castro MI (2010) Analysis of early human neural crest development. Dev Biol. https://doi.org/10.1016/j.ydbio.2010.05.012

18. Tomellini E, Touil Y, Lagadec C, Julien S, Ostyn P, Ziental-Gelus N, Meignan S, Lengrand J, Adriaenssens E, Polakowska R, Le Bourhis X (2015) Nerve growth factor and prongf simultaneously promote symmetric self-renewal, quiescence, and epithelial to mesenchymal transition to enlarge the breast cancer stem cell compartment. Stem Cells. https://doi.org/10.1002/stem.1849 
19. Okumura T, Shimada Y, Imamura M, Yasumoto S (2003) Neurotrophin receptor p75NTR characterizes human esophageal keratinocyte stem cells in vitro. Oncogene. https://doi.org/10.1038/sj.onc.1206525

20. Di Girolamo N, Sarris M, Chui J, Cheema H, Coroneo MT, Wakefield D (2008) Localization of the lowaffinity nerve growth factor receptor p75 in human limbal epithelial cells. J Cell Mol Med. https://doi.org/10.1111/j.1582-4934.2008.00290.x

21. Li X, Shen Y, Di B, Li J, Geng J, Lu X, He Z (2012) Biological and clinical significance of p75 NTR expression in laryngeal squamous epithelia and laryngocarcinoma. Acta Otolaryngol. https://doi.org/10.3109/00016489.2011.639086

22. Tsang JYS, Wong KHY, Lai MWH, Lacambra MD, Ko CW, Chan SK, Lam CCF, Yu AMC, Tan PH, Tse GM (2013) Nerve growth factor receptor (NGFR): A potential marker for specific molecular subtypes of breast cancer. J Clin Pathol 66:291-296 . https://doi.org/10.1136/jclinpath-2012-201027

23. Aragona M, Panetta S, Silipigni AM, Romeo DL, Pastura G, Mesiti M, Cascinu S, La Torre F (2001) Nerve growth factor receptor immunoreactivity in breast cancer patients. Cancer Invest 19:692-697 . https://doi.org/10.1081/CNV-100106144

24. Liu T, Zhang L, Joo D, Sun SC (2017) NF-kB signaling in inflammation. Signal Transduct. Target. Ther.

25. Dolle L, Adriaenssens E, Yazidi-Belkoura I, Bourhis X, Nurcombe V, Hondermarck H (2005) Nerve Growth Factor Receptors and Signaling in Breast Cancer. Curr Cancer Drug Targets. https://doi.org/10.2174/1568009043332853

26. Xia Y, Shen S, Verma IM (2014) NF-kB, an active player in human cancers. Cancer Immunol. Res.

27. Pratt MAC, Tibbo E, Robertson SJ, Jansson D, Hurst K, Perez-Iratxeta C, Lau R, Niu MY (2009) The canonical NF-B pathway is required for formation of luminal mammary neoplasias and is activated in the mammary progenitor population. Oncogene. https://doi.org/10.1038/onc.2009.131

28. Xia L, Tan S, Zhou Y, Lin J, Wang H, Oyang L, Tian Y, Liu L, Su M, Wang H, Cao D, Liao Q (2018) Role of the NFKB-signaling pathway in cancer. Onco Targets Ther. https://doi.org/10.2147/OTT.S161109

29. Livak KJ, Schmittgen TD (2001) Analysis of relative gene expression data using real-time quantitative PCR and the 2- $\triangle \triangle C T$ method. Methods. https://doi.org/10.1006/meth.2001.1262

30. Kikin O, D’Antonio L, Bagga PS (2006) QGRS Mapper: A web-based server for predicting Gquadruplexes in nucleotide sequences. Nucleic Acids Res. https://doi.org/10.1093/nar/gkl253

31. Kreft L, Soete A, Hulpiau P, Botzki A, Saeys Y, De Bleser P (2017) ConTra v3: A tool to identify transcription factor binding sites across species, update 2017. Nucleic Acids Res. https://doi.org/10.1093/nar/gkx376 
32. Mochizuki M, Tamai K, Imai T, Sugawara S, Ogama N, Nakamura M, Matsuura K, Yamaguchi K, Satoh K, Sato I, Motohashi H, Sugamura K, Tanaka N (2016) CD271 regulates the proliferation and motility of hypopharyngeal cancer cells. Sci Rep. https://doi.org/10.1038/srep30707

33. Huang MC, Chu I Te, Wang ZF, Lin S, Chang TC, Chen CT (2018) A g-quadruplex structure in the promoter region of CLIC4 functions as a regulatory element for gene expression. Int J Mol Sci. https://doi.org/10.3390/ijms19092678

34. Oeckinghaus A, Ghosh S (2009) The NF-kappaB family of transcription factors and its regulation. Cold Spring Harb. Perspect. Biol.

35. Khan MA, Tania M, Fu S, Fu J (2017) Thymoquinone, as an anticancer molecule: From basic research to clinical investigation. Oncotarget

36. Dastjerdi MN, Mehdiabady EM, Iranpour FG, Bahramian H (2016) Effect of thymoquinone on P53 gene expression and consequence apoptosis in breast cancer cell line. Int J Prev Med. https://doi.org/10.4103/2008-7802.180412

37. Ayob AZ, Ramasamy TS (2018) Cancer stem cells as key drivers of tumour progression. J. Biomed. Sci.

38. Civenni G, Walter A, Kobert N, Mihic-Probst D, Zipser M, Belloni B, Seifert B, Moch H, Dummer R, Van Den Broek M, Sommer L (2011) Human CD271-positive melanoma stem cells associated with metastasis establish tumor heterogeneity and long-term growth. Cancer Res. https://doi.org/10.1158/00085472.CAN-10-3997

39. Li S, Yue D, Chen X, Wang L, Li J, Ping Y, Gao Q, Wang D, Zhang T, Li F, Yang L, Huang L, Zhang Y (2015) Epigenetic regulation of CD271, a potential cancer stem cell marker associated with chemoresistance and metastatic capacity. Oncol Rep. https://doi.org/10.3892/or.2014.3569

40. Chung MK, Jung YH, Lee JK, Cho SY, Murillo-Sauca O, Uppaluri R, Shin JH, Sunwoo JB (2018) CD271 confers an invasive and metastatic phenotype of head and neck squamous cell carcinoma through the upregulation of slug. Clin Cancer Res. https://doi.org/10.1158/1078-0432.CCR-17-0866

41. Elkashty OA, Elghanam GA, Su X, Liu Y, Chauvin PJ, Tran SD (2020) Cancer stem cells enrichment with surface markers CD271 and CD44 in human head and neck squamous cell carcinomas. Carcinogenesis. https://doi.org/10.1093/carcin/bgz182

42. Redmer T, Welte Y, Behrens D, Fichtner I, Przybilla D, Wruck W, Yaspo ML, Lehrach H, Schäfer R, Regenbrecht CRA (2014) The nerve growth factor receptor CD271 is crucial to maintain tumorigenicity and stem-like properties of melanoma cells. PLoS One. https://doi.org/10.1371/journal.pone.0092596

43. Gündüz UR, Gunaldi M, Isiksacan N, Gündüz S, Okuturlar Y, Kocoglu H (2016) A new marker for breast cancer diagnosis, human epididymis protein 4: A preliminary study. Mol Clin Oncol. 
44. Kristiansen G, Winzer KJ, Mayordomo E, Bellach J, Schlüns K, Denkert C, Dahl E, Pilarsky C, Altevogt P, Guski H, Dietel M (2003) CD24 Expression Is a New Prognostic Marker in Breast Cancer. Clin Cancer Res

45. Kwon MJ, Han J, Seo JH, Song K, Jeong HM, Choi JS, Kim YJ, Lee SH, Choi Y La, Shin YK (2015) $\mathrm{CD} 24$ overexpression is associated with poor prognosis in luminal a and triple-negative breast cancer. PLoS One. https://doi.org/10.1371/journal.pone.0139112

46. Kanyilmaz G, Benli Yavuz B, Aktan M, Karaagac M, Uyar M, Findik S (2019) Prognostic Importance of Ki-67 in Breast Cancer and Its Relationship with Other Prognostic Factors. Eur J Breast Heal. https://doi.org/10.5152/ejbh.2019.4778

47. Liang L, Coudiere-Morrison L, Tatari N, Stromecki M, Fresnoza A, Porter CJ, Del Bigio MR, Hawkins C, Chan JA, Ryken TC, Taylor MD, Ramaswamy V, Werbowetski-Ogilvie TE (2018) CD271p cells are diagnostic and prognostic and exhibit elevated mapk activity in SHH medulloblastoma. Cancer Res. https://doi.org/10.1158/0008-5472.CAN-18-0027

48. Sethi G, Kwang SA, Aggarwal BB (2008) Targeting nuclear factor-kB activation pathway by thymoquinone: Role in suppression of antiapoptotic gene products and enhancement of apoptosis. Mol Cancer Res. https://doi.org/10.1158/1541-7786.MCR-07-2088

49. Salem AA, El Haty IA, Abdou IM, Mu Y (2015) Interaction of human telomeric G-quadruplex DNA with thymoquinone: A possible mechanism for thymoquinone anticancer effect. Biochim Biophys Acta - Gen Subj. https://doi.org/10.1016/j.bbagen.2014.10.018

\section{Tables}

Table 1: List of primers used for quantitative Real Time PCR Assay 


\begin{tabular}{|lllll|}
\hline Gene & Primer & Sequence $\left(\mathbf{5}^{\prime} \mathbf{- 3}^{\prime}\right)$ & $\begin{array}{l}\text { Annealing Temperature } \\
\left({ }^{\circ} \mathrm{C}\right)\end{array}$ & $\begin{array}{c}\text { Amplicon Size } \\
(\mathbf{b p})\end{array}$ \\
\hline CD271 & Forward & GTATTCCGACGAGGCCAAC & 58 & 140 \\
& Reverse & TGGACCGTGTAATCCAACG & & 120 \\
\hline $\begin{array}{l}\text { NF- } \\
\text { KB1 }\end{array}$ & Forward & TTTCTTCCGGATAGCACTGG & 56 & 103 \\
\hline Sox2 & Forward & TGATGGAGACGGAGCTGAA & 57 & 140 \\
& Reverse & GGGCTGTTTTTCTGGTTGC & & 109 \\
\hline Nanog & Forward & GATTTGTGGGCCTGAAGAAA & 57 & \\
\hline B-actin & Forward & CTGAACCCCAAGGCCAAC & 59 & \\
& Reverse & AGAGGCGTACAGGGATAGCA & & \\
\hline
\end{tabular}

Note: The amplicon size listed are correspond to the cDNA fragment used for Real Time PCR.

Table 2: Clinical pathological Distribution of samples $(n=60)$ 


\begin{tabular}{|ll|}
\hline Parameters & Number of Cases (\%) \\
\hline Age & \\
\hline G1(20-40) & $14(23)$ \\
\hline G2(41-60) & $36(60)$ \\
\hline G3(61-80) & $10(17)$ \\
\hline Cancer Types & \\
\hline DCIS & $8(13)$ \\
\hline IDC & $44(74)$ \\
\hline ILC & $8(13)$ \\
\hline Grade & \\
\hline I & $0(0)$ \\
\hline II & $41(68)$ \\
\hline III & $19(32)$ \\
\hline Estrogen Receptor & \\
\hline ER+ & $41(68)$ \\
\hline ER- & $19(32)$ \\
\hline Progesterone Receptor & \\
\hline PR+ & $44(73)$ \\
\hline PR- & $16(27)$ \\
\hline Her2 Receptor & \\
\hline Her2+ & $41(68)$ \\
\hline Her2- & \\
\hline
\end{tabular}

Figures 


\section{Fig 1}

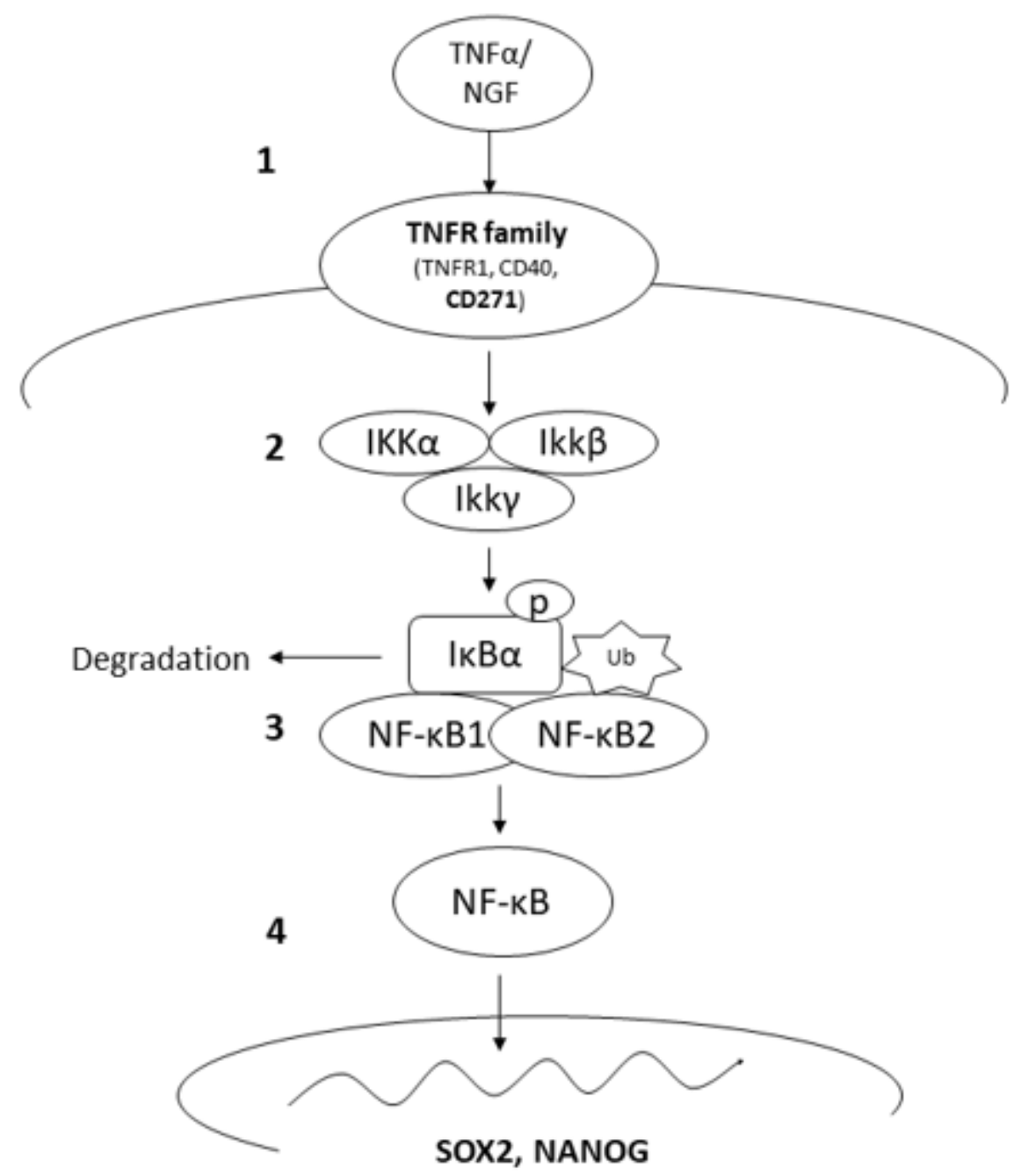

Figure 1

NF-KB pathway: 1. Ligand binds to its tumor necrosis factor receptor (TNFR). 2. It activates IkappaB kinases (IKKs complex) 3. IkappaB Kinase $\beta(\mathrm{Ikk} \beta$ ) then induces phosphorylation of the inhibitory factor IKBa leading to the ubiquitination and degradation by proteosome, and thus releasing NF-KB factors (p50/p65) 4 Translocation of NF-KB factors (p50/p65) to the nucleus and activation of target genes such as Sox2 and Nanog. 


\section{Fig 2}

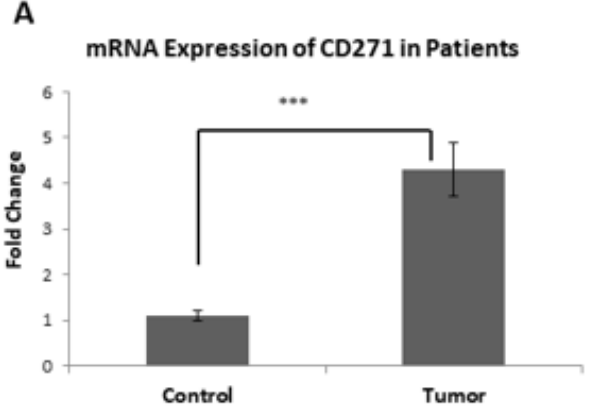

C

mRNA Expression level in MCF7 and MCF7-CSCs

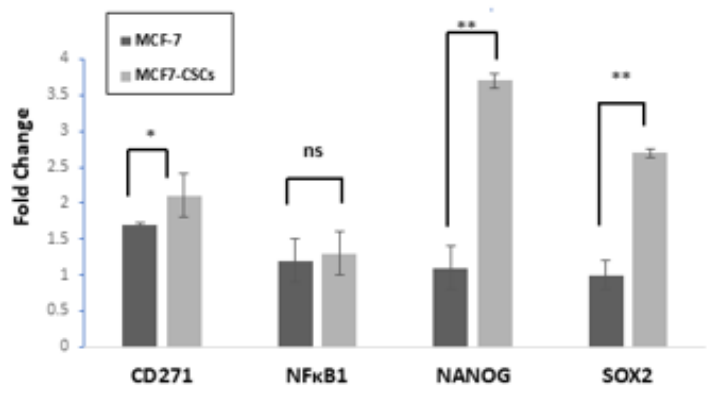

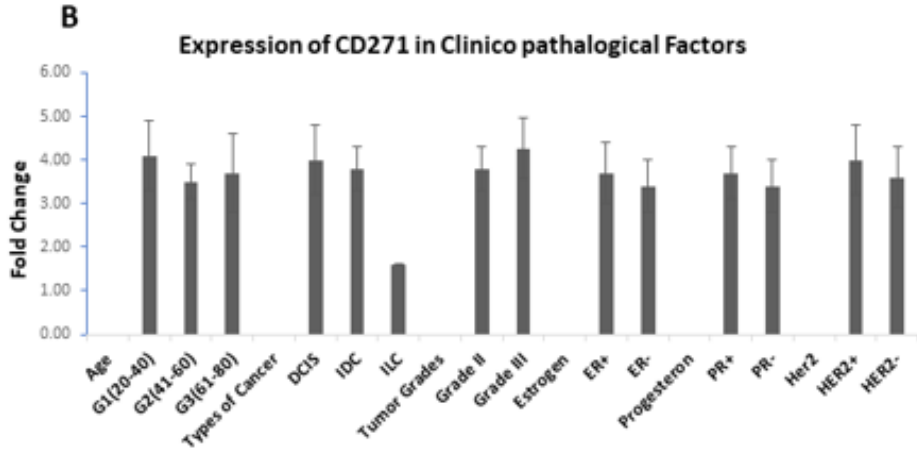

D

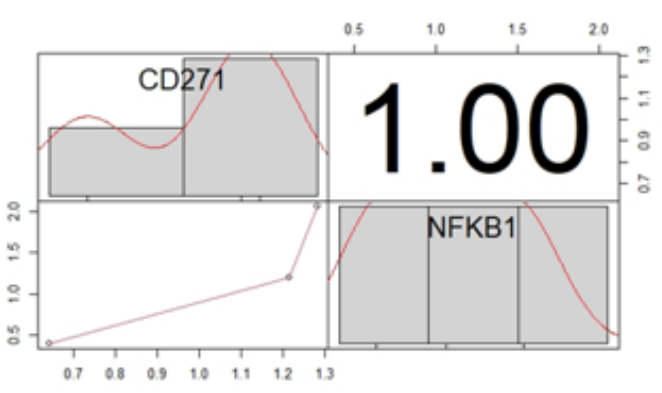

\section{Figure 2}

The relative expression of CD271 mRNA in patients as compared to control The bar graph shows fold change ( $\left.2^{\wedge}-\Delta \Delta C t\right)$ of $C D 271$ normalized against $\beta$-actin (A). The expression of CD271 in relation to different clinic-pathological Factors. The bars show the fold change of CD271 in Age group $(p=0.8)$, Types of cancer: Ductal carcinoma insitu (DCIS), Invasive ductal carcinoma (IDC), invasive lobular carcinoma (ILC) $(p=0.5)$, Tumor grades $(p=0.7)$, Estrogen receptor $(p=0.8)$, Progesterone receptor $(p=0.2)$, and Human epidermal growth factor receptor Her2 receptor $(p=0.7)(B)$. The bar graph shows induced level of CD271 ( $p=0.01), N F k B 1$, Nanog $(p=0.002)$ and sox2 $(p=0.003)$ in MCF-CSCs as compared to MCF7 (A). Correlation analysis of CD271 expression with NF-kB1 expression (C) CSCs Correlation study done by Kendall rank correlation test shows significant $(\mathrm{p}=0.01)$ and strong positive $($ tau $=1)$ correlation between CD271 and NF-KB1 expression (D). Error bar represents standard error of means. 


\section{Fig 3}

A

Binding of NFkB1 at G-quadraplex sequences of CD271 promoter

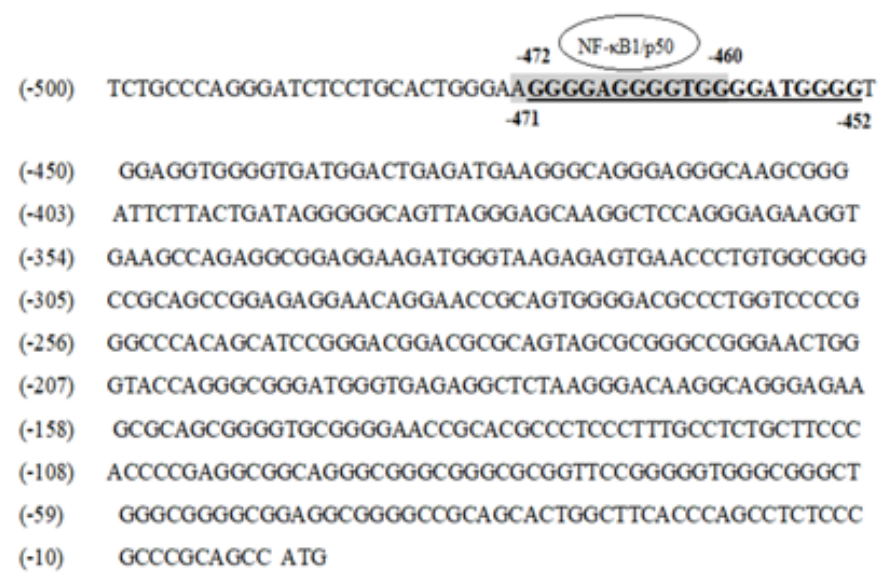

B

Transcription Interference by TQ at promoter region of CD271

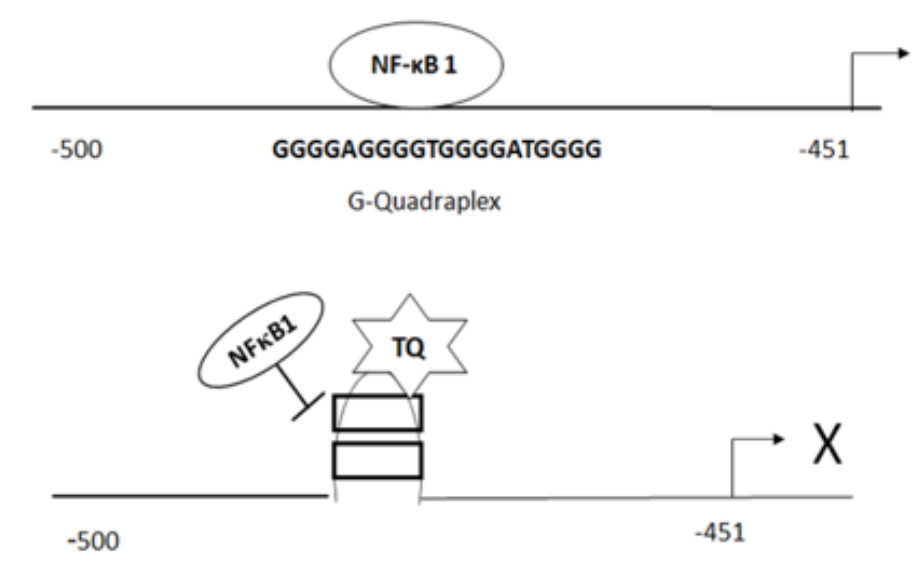

\section{Figure 3}

Schematic representation of CD271 promoter region 500bp upstream of transcription start site (TSS). Gquadraplex (G-score 62 ) is identified at region $-452 \mathrm{bp}$ to $-471 \mathrm{bp}$ and indicated by bold letters and line. Binding site of NF-KB1 has been identified at -460 to -472 bp (A). Diagrammatic illustration showing Gquadraplex sequences in CD271 promoter region and binding of thymoquinone at G-quadraplex region of promoter of CD271. TQ binding stabilize the G-quadraplex and cause the hindrance of p50(NF-kB1) to bind to the promoter and halt the transcription of CD271 (B). 


\section{Fig4}
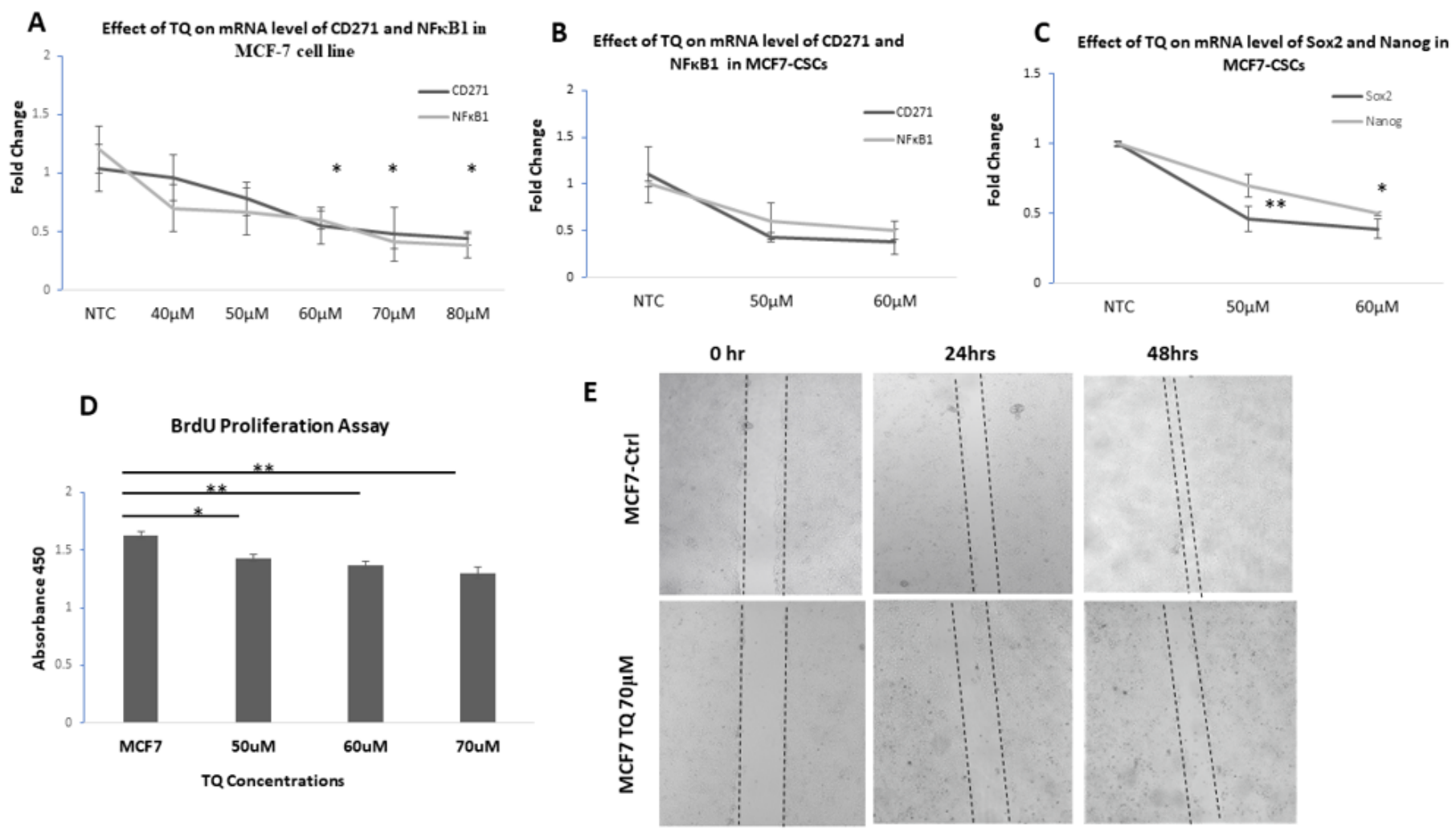

\section{Figure 4}

The inhibitory effects of thymoquinone TQ on expression of mRNA in MCF-7 cell line. The line graph shows reduction of CD271 and NFKB1 mRNA level by increasing the concentration of TQ in MCF-7 cell line. The significant down regulation of $C D 271$ is shown by $60 \mu \mathrm{M}(p=0.01), 70 \mu \mathrm{M}(\mathrm{p}=0.01)$ and $80 \mu \mathrm{M}$ $(p=0.04)(A)$. The line graph shows reduction of mRNA level of CD271 and NF-kB1 in MCF7-CSCs (B) The overall reduction of Sox2 $(p=0.002)$ with increasing the concentration of TQ and Nanog $(p=0.02)$ at $60 \mu M$ TQ (C). The proliferation assay showed the significant negative effect of TQ on the proliferation of MCF-7 cells at $50 \mu \mathrm{M}(p=0.03), 60 \mu \mathrm{M}(p=0.007)$ and $70 \mu \mathrm{M}(p=0.001)(D)$. The scratch wound healing assay were performed to assess the effect of TQ on the movement of MCF-7 cells for $48 \mathrm{hrs}$. (E). 


\section{Fig 5}

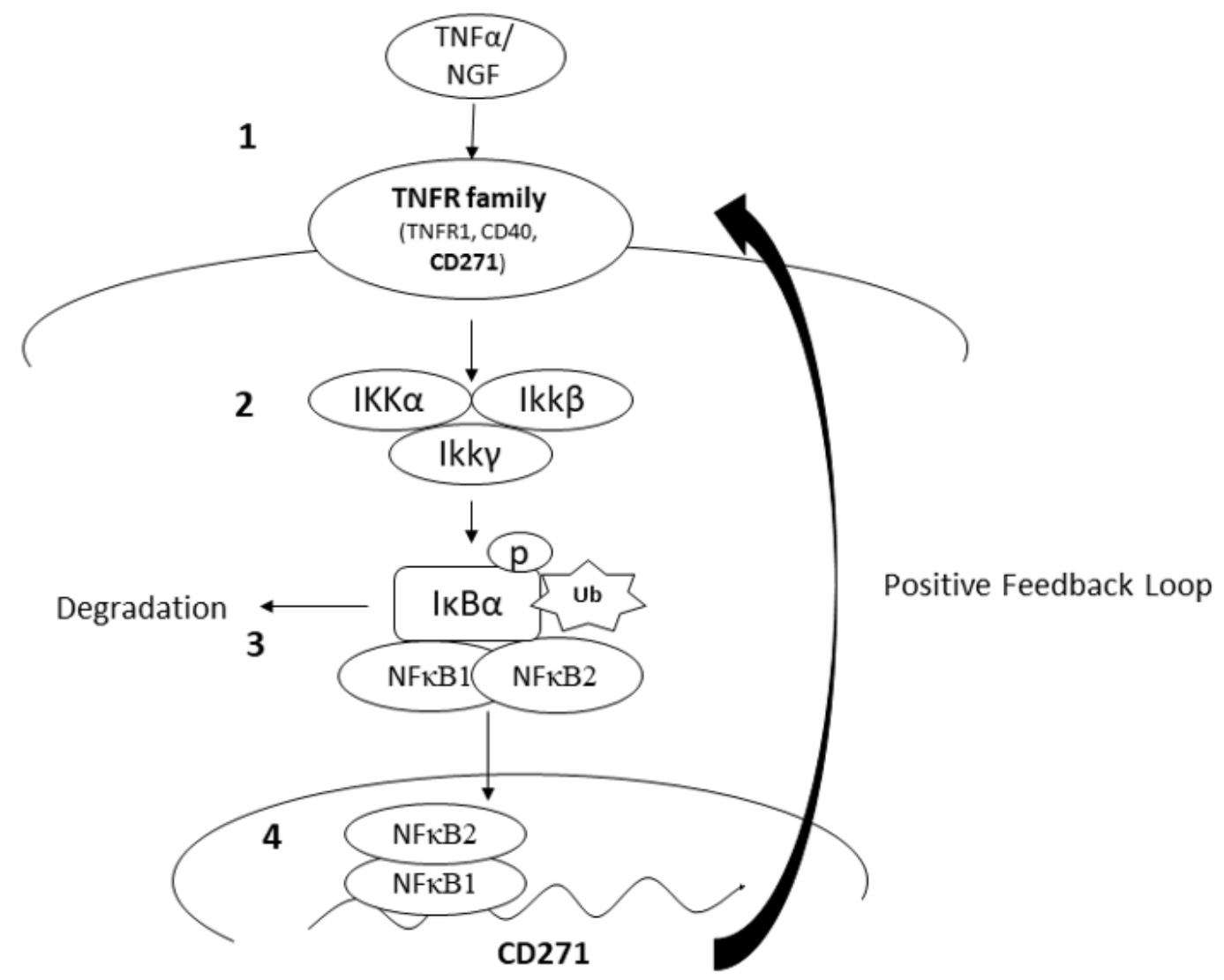

Figure 5

Positive feedback loop of CD271: 1. Ligand binds to its tumor necrosis factor receptor (TNFR). 2. It activates IkappaB kinases (IKKs complex) 3. IkappaB Kinase $\beta(\operatorname{Ikk} \beta)$ then induces phosphorylation of the inhibitory factor $\mathrm{IKBa}_{\mathrm{K}}$ leading to the ubiquitination and degradation by proteosome, as a result of which NF-kB factors (NF-kB1 and NF-KB2) is released. 4 NF-kB factors (NF-kB1 and NF-KB2) are translocated to the nucleus and activates CD271. 